\title{
Tumor Protein 63
}

National Cancer Institute

\section{Source}

National Cancer Institute. Tumor Protein 63. NCI Thesaurus. Code C91793.

Tumor protein 63 ( $680 \mathrm{aa}, \sim 77 \mathrm{kDa}$ ) is encoded by the human TP63 gene. This protein plays a role in the mediation of both transcription and limb morphogenesis. 